\title{
SEISMIC DESIGN OF LOW-RISE OFFICE BUILDINGS ACCORDING TO ROMANIAN SEISMIC CODES. CASE STUDY.
}

\begin{abstract}
ANA-MARIA GHIŢĂ - Assistant Lecturer, PhD, Technical University of Civil Engineering, The Faculty of Civil, Industrial and Agricultural Buildings

Abstract: The paper presents a study case and highlights the changes made by the new, in force, seismic Code P100-1/2013 in comparison with the former P100-1/2006, concerning the reinforced concrete frame structural systems design. Different seismic designed RC frames systems, compatible with modern office requirements, were studied. The influence of the earthquake codes provisions on design of regular buildings, having openings fitted for open spaces, with a story height of $3.50 \mathrm{~m}$, was assessed. The benefits of tubular structures, with rigid frames made of closely spaced columns on the building perimeter, were analyzed as well. The results of the study case are presented emphasizing the consequences of the application of the new seismic Code on the computation of the reinforced concrete frame structures.
\end{abstract}

Keywords: space flexibility, seismic performance, tubular structure

\section{Introduction}

Design codes evolve from one version to another. This brings changes in structural design and analysis methods together with numerical changes of the design coefficients $[1,2]$. Numerical study cases show how and if these changes of the codes improve the behavior of structures and which the additional costs for execution are.

The paper intends to study comparatively the modification effects of the seismic design code P100/1 on dimensioning of the reinforced concrete frame structures representative for low-rise office buildings. The study analyses the input data, meaning the intensity of the seismic action, and also the changes brought to the method of dimensioning the concrete elements, the reinforcement and the minimum reinforcement percentages imposed by codes [4, 6]. The comparisons are made designing several reinforced concrete frame structures [7], with different numbers of stories.

The novelty of the study case consists in emphasizing the implications of the in force seismic design code provisions to the costs of the RC frames structural systems, with respect to the number of stories and the type of structure. The paper shows the influence of the new seismic code on the investments in this type of buildings in Bucharest [5].

\section{A comparative overview of the former and in force seismic code P100 provisions}

\subsection{Seismic action}

One of the changes brought by the present seismic design code, from 2013, is to establish the mean recurrence interval of 225 years for the design ground acceleration value, $a_{g}$. In this way, $a_{g}$ has values between $0.1 \mathrm{~g}$ and $0.4 \mathrm{~g}$. The former design code, from 2006, prescribed for the peak ground acceleration $\mathrm{a}_{\mathrm{g}}$ values between $0.08 \mathrm{~g}$ and $0.32 \mathrm{~g}$, corresponding to a return period of 100 years. For Bucharest, the city with the largest built environment in Romania, the seismic acceleration became $\mathrm{a}_{\mathrm{g}}=0.30 \mathrm{~g}$ comparing with $0.24 \mathrm{~g}$ from the old code, i.e. an increase of $25 \%$.

The normalized elastic acceleration response spectrumS $(\mathrm{T})$ changed, using a different dynamic amplification factor $\beta_{0}=2.5$, compared to $\beta_{0}=2.75$ from the former code, in this way appearing a decrease of the value with $10 \%$. 
a)

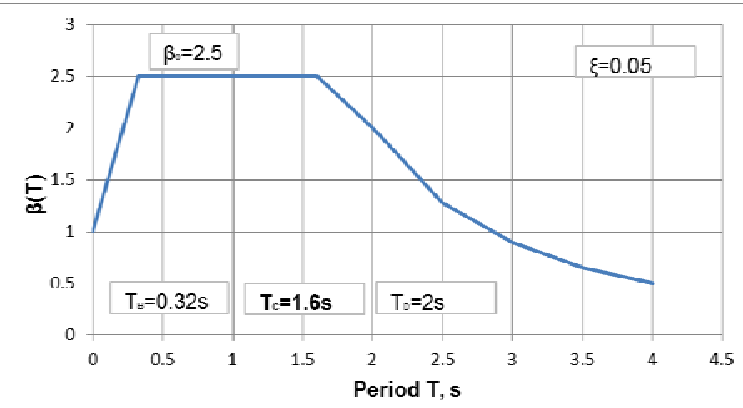

Fig. 1 - The normalised elastic acceleration response spectra - a) P100-1/2013 [2]; b)P100-1/2006 [1]

The classification criteria for the importance classes also changed, especially those concerning the $\mathrm{II}^{\text {nd }}$ and the III ${ }^{\text {rd }}$ importance classes. Consequently, the office buildings correspond to the II ${ }^{\text {nd }}$ class if the number of persons in the area of the building is larger than 300 persons and not if the number is larger than 400 as it was written in the former code. A new criterion for the classification into importance classes, included in P100-1/2013, is the total height of the building. Buildings higher than $45 \mathrm{~m}$ belong to the first class of importance, lower than $28 \mathrm{~m}$ belong to the third class and between these values to the second class of importance. The importance-exposure coefficients for seismic action $\gamma_{\mathrm{I}, \mathrm{e}}$ have the same values in both codes.

The evaluation of the base shear force for the design of the structures using the static equivalent seismic force is:

$$
\mathrm{F}_{\mathrm{b}}=\gamma_{\mathrm{I}, \mathrm{e}} \cdot \mathrm{S}_{\mathrm{d}}\left(\mathrm{T}_{1}\right) \cdot \mathrm{m} \cdot \lambda
$$

The equation is identical in both codes. The design spectrum $\mathrm{S}_{\mathrm{d}}\left(\mathrm{T}_{1}\right)$, is influenced by the value of the behavior factor $\mathrm{q}$. For reinforced concrete frame structures, designed with high ductility capacity:

$$
\mathrm{q}=5 \alpha_{\mathrm{u}} / \alpha_{1}
$$

where $\alpha_{u} / \alpha_{1}=1.35$ for multistorey and multi-bay reinforced concrete frames structures.

\subsection{Design requirements for reinforced concrete frames}

Checking of the lateral displacements for ultimate limit state is made in both codes using the equation:

$$
\mathrm{d}_{\mathrm{r}}^{\mathrm{ULS}}=\mathrm{c} \cdot \mathrm{q} \cdot \mathrm{d}_{\mathrm{re}} \leq \mathrm{d}_{\mathrm{r}, \mathrm{a}}^{\mathrm{ULS}}
$$

where "c", the displacement amplification coefficient. According to P100/1-2013, it can be calculated as:

$$
1 \leq 3-2.3 \cdot \frac{\mathrm{T}_{1}}{\mathrm{~T}_{\mathrm{C}}}<\frac{\sqrt{\mathrm{T}_{\mathrm{C}} \mathrm{q}}}{1.7}
$$

where $T_{1}$ is the period of the first eigenmode and $T_{C}$ is the upper limit of the period of the constant spectral acceleration branch.

The code P100-1/2006 prescribes the following equation:

$$
1 \leq 3-2.5 \cdot \frac{\mathrm{T}_{1}}{\mathrm{~T}_{\mathrm{C}}} \leq 2
$$

It can be seen that the new design code considers larger amplifications of the lateral displacements, but the upper bound is smaller. The values of the upper bound of the displacement amplification coefficient $\mathrm{c}_{\max }$ can be observed in the following table.

Maximum values for displacement amplification coefficient for ULS

\begin{tabular}{|c|c|c|}
\hline $\mathrm{T}_{\mathrm{C}}(\mathrm{s})$ & $\mathrm{c}_{\max , 2013}$ & $\mathrm{c}_{\max , 2006}$ \\
\hline 0.7 & 1.28 & 2 \\
\hline 1.0 & 1.53 & 2 \\
\hline 1.6 & 1.93 & 2 \\
\hline
\end{tabular}


The values from the table are computed for $\mathrm{q}=6.75$.

Checking of the lateral displacements for serviceability limit state is made in both codes using the equation:

$$
\mathrm{d}_{\mathrm{r}}^{\mathrm{SLS}}=v \cdot \mathrm{q} \cdot \mathrm{d}_{\mathrm{re}} \leq \mathrm{d}_{\mathrm{r}, \mathrm{a}}^{\mathrm{SLS}}
$$

The reduction factor $v$ has the value 0.5 in P100-1/2013, while the former code prescribes two values for $v$, of 0.4 for the first and second class of importance and 0.5 for the third and fourth class. In this way, at serviceability limit state, the condition of limiting the displacements has become more restrictive for buildings with higher importance.

In order to ensure the local ductility demands for the columns, P100-1/2013 requires that the normalized medium axial stress $v_{\mathrm{d}}$ be smaller than 0.45 for structures with high ductility. Larger values, up to 0.55 , can be used only by performing the checking of the column ductility.

In addition, for the critical zones from the base of the columns, the new code requires, for high ductility class, to fulfill two minimum percentages of transversal reinforcement: one geometrical reinforcement coefficient, $\rho_{\mathrm{w}, \min }=0,005$, identical with the former one, and one mechanical reinforcement coefficient, $\omega_{\mathrm{wd}, \mathrm{min}}=0,12$. Checking of the last coefficient was introduced for the first time in the Romanian seismic code in 2013.

For beams, the new code P100, demands new rules for critical zones dimensioning at shear force, according to the algebraic value of the ratio $\zeta$ between the minimum and maximum shear force from the design section, at each end of the beam. If the value

$$
\begin{aligned}
& \zeta<-0,5 \text { and } \\
& \left|\mathrm{V}_{\mathrm{Ed}}\right|_{\max }>(2+\zeta) \mathrm{b}_{\mathrm{w}} \cdot \mathrm{d} \cdot \mathrm{f}_{\mathrm{ctd}}
\end{aligned}
$$

than half of the design shear force is taken by inclined reinforcement bars placed in two directions, inclined by $\pm 45^{\circ}$ from the beam longitudinal axis. In the previous equation $b_{w}$ is the width of the web of the beam, $d$ is the effective beam depth and $f_{\text {ctd }}$ is the design value of the tensile strength of concrete.

These are some of the changes implemented by the design code P100-1/2013 concerning the reinforced concrete frame systems that bring changes to the dimensions of the concrete elements and of the reinforcement quantities.

\section{Case study for office buildings with reinforced concrete frame structures}

The study case contains the results from the design of a number of RC frame structures, suitable for open-space office buildings. The final objective is to provide a comparative analysis of this type of structures in order to appraise the influence of the new seismic design code provisions on construction materials consumption.

\subsection{Description of the structures}

The study case was performed for buildings having a rectangular shape, a number of $3,4,5$ or 6 storeys, and the structure consisting in reinforced concrete frames arranged in two orthogonal directions. The floors were considered made of cast-in-place reinforced concrete slabs and secondary beams.

Two types of structures were studied, named $\mathrm{A}$ and $\mathrm{B}$, having the main dimensions in plan $6,00 \times 9,00 \mathrm{~m}$ and $6,00 \times 6,00 \mathrm{~m}$. The total length of the building is $54,00 \mathrm{~m}$ and width $30,00 \mathrm{~m}$. The story height is $3,50 \mathrm{~m}$, to provide the necessary space for the heat, air conditioning and ventilation ducts, data and electrical cables and installation of a suspended ceiling. [9, 11].

The first structural system used, named A, has the columns spaced at $6,00 \mathrm{~m}$ and $9,00 \mathrm{~m}$ in one direction and at $6,00 \mathrm{~m}$ in the other. For the reinforced concrete floor system, was chosen the 
solution with main and additional secondary beams and flat slabs. Finally the slab was divided by the beams in $3,00 \times 3,00 \mathrm{~m}$ areas and the thickness of the slab was considered $12 \mathrm{~cm}$.

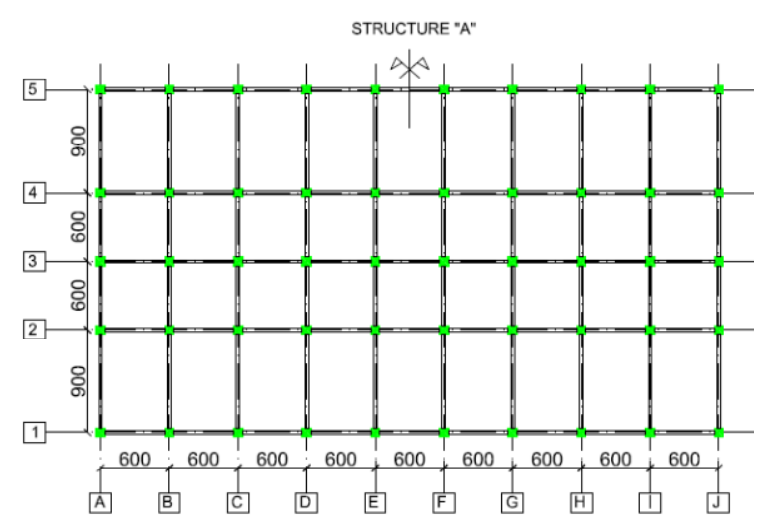

Fig. 2 - Layout of the RC frame structure A

The second structural system, used for the study, named B, was another RC frame system, with the perimeter columns less spaced, at $3,00 \mathrm{~m}$, to create a perimetral tubular frame system, keeping the inside openings of $6,00 \times 6,00 \mathrm{~m}$ and $6,00 \times 9,00 \mathrm{~m}$.

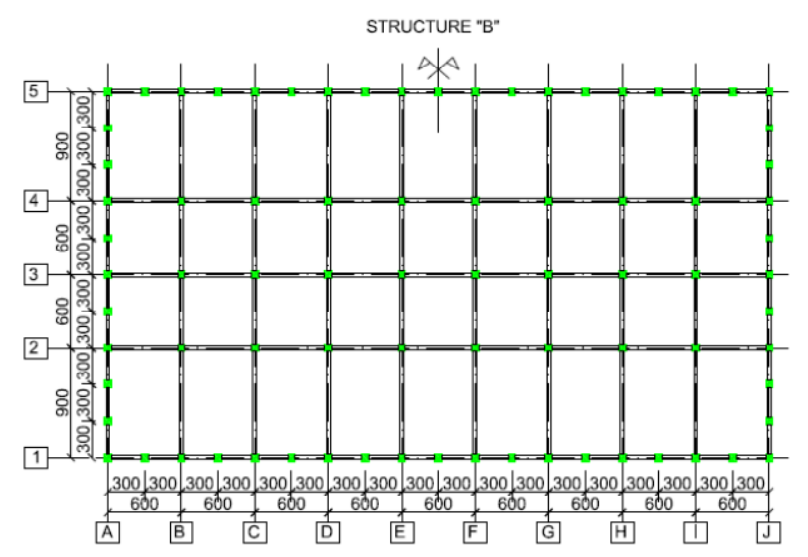

Fig. 3 - Layout of the RC frame structure B, with edge columns less spaced, like a tube

The buildings were considered to be placed in Bucharest, where the design seismic acceleration is:

- $\mathrm{ag}=0.24 \mathrm{~g}$, for seismic events having the mean recurrence interval of 100 years, according to former code P100-1/2006

- $\quad \mathrm{ag}=0.30 \mathrm{~g}$, for seismic events having the mean recurrence interval of 225 years, according to former code P100-1/2013

The period Tc for the response spectrum of this location, according to both codes is 1.6 seconds.

The office buildings have a surface of $1620 \mathrm{~m} 2$ on each level. The average floor area requirement for each workstation, including the office equipment and space to operate it, is 8-10 $\mathrm{m} 2$ and tends to become $12-15 \mathrm{~m} 2$, except the management personnel offices that can reach $30 \mathrm{~m} 2$ or more [12]. Considering that, it means that over 400 persons can be present in the total exposed aria. Consequently, according to both seismic code provisions, the buildings are included in the second class of importance, with the importance factor $\gamma \mathrm{I}=1,2$.

The concrete used in the study for the main structural elements is C35/45 and the reinforcement steel is S355, with properties defined according to the Romanian standard SR EN 1992-1-1, "Design of concrete structures" [4].

The gravity loads considered were the building self-weight, the live load for office buildings - $2 \mathrm{kN} / \mathrm{m} 2$ for work spaces and $3 \mathrm{kN} / \mathrm{m} 2$ for circulation zones and the snow load on the terrace roof $\mathrm{s}=2 \mathrm{kN} / \mathrm{m} 2$.

The evaluation of the seismic loads was made for the current design method and for a spatial structural model. 
The shear force at the base of the structure, corresponding to the fundamental vibration mode, for each main horizontal direction is:

$$
\begin{aligned}
& F_{b}=0.0997 G \text { according to } P 100-1 / 2006 \\
& F_{b}=0.1133 G \text { according to } P 100-1 / 2013
\end{aligned}
$$

where the behaviour coefficient of the structure $q=5 \alpha_{u} / \alpha_{1}$ is taken for redundant reinforced concrete frame structures, regular in plan and elevation, for ductility class $H$ and $\lambda=0.85$ for structures having more than 2 levels and $\mathrm{T}_{1}<\mathrm{T}_{\mathrm{C}}$.

It can be seen that the base shear force has an increase of $13,6 \%$ in the new seismic design Code, in comparison with the former one.

\subsection{Analysis of the results}

After checking the relative displacement for the two limit states, the ultimate limit state and the serviceability limit state, the dimensions of the concrete elements, beams and columns, for the analyzed structures, have resulted.

The cross-sections of the concrete elements, for the two analyzed structures, A and B, are listed in table 2.

Table 2

Concrete elements cross-sections

\begin{tabular}{|c|c|c|c|c|c|}
\cline { 3 - 5 } \multicolumn{2}{c|}{} & \multicolumn{2}{c|}{ Structure A } & \multicolumn{2}{c|}{ Structure B } \\
\cline { 3 - 6 } \multicolumn{2}{c|}{} & P100/2006 & P100/2013 & P100/2006 & P100/2013 \\
\hline \multirow{3}{*}{3 storeys } & Columns (bxh) cm & $55 \times 55$ & $65 \times 65$ & $50 \times 50$ & $50 \times 50$ \\
\cline { 2 - 6 } & Longitudinal beams (bxh) cm & $30 \times 60$ & $30 \times 60$ & $30 \times 60$ & $30 \times 60$ \\
\cline { 2 - 6 } & Transversal beams (bxh) cm & $30 \times 75$ & $30 \times 75$ & $30 \times 75$ & $30 \times 75$ \\
\hline \multirow{3}{*}{4 storeys } & Columns (bxh) cm & $70 \times 70$ & $80 \times 80$ & $55 \times 55$ & $60 \times 60$ \\
\cline { 2 - 6 } & Longitudinal beams (bxh) cm & $30 \times 60$ & $30 \times 60$ & $30 \times 60$ & $30 \times 60$ \\
\cline { 2 - 6 } & Transversal beams (bxh) cm & $30 \times 75$ & $30 \times 75$ & $30 \times 75$ & $30 \times 75$ \\
\hline \multirow{3}{*}{5 storeys } & Columns (bxh) cm & $85 \times 85$ & $105 \times 105$ & $65 \times 65$ & $75 \times 75$ \\
\cline { 2 - 6 } & Longitudinal beams (bxh) cm & $30 \times 60$ & $30 \times 65$ & $30 \times 60$ & $30 \times 60$ \\
\cline { 2 - 6 } & Transversal beams (bxh) cm & $30 \times 75$ & $30 \times 75$ & $30 \times 75$ & $30 \times 75$ \\
\hline \multirow{3}{*}{6 storeys } & Columns (bxh) cm & $105 \times 105$ & $150 \times 150$ & $70 \times 70$ & $105 \times 105$ \\
\cline { 2 - 6 } & Longitudinal beams (bxh) cm & $30 \times 60$ & $30 \times 60$ & $30 \times 60$ & $30 \times 60$ \\
\cline { 2 - 6 } & Transversal beams (bxh) cm & $30 \times 75$ & $30 \times 75$ & $30 \times 75$ & $30 \times 75$ \\
\hline
\end{tabular}

For the A type structures, designed according to both seismic codes, different values for $\mathrm{c}$ coefficient were obtained, shown in table 3.

Values of displacement amplification coefficient for structure A

\begin{tabular}{|c|c|c|c|}
\cline { 3 - 4 } \multicolumn{2}{c|}{} & \multicolumn{2}{c|}{$\mathrm{c}$} \\
\cline { 3 - 4 } \multicolumn{2}{c|}{} & Value & Increase \% \\
\hline 3 storeys & $\mathrm{P} 100 / 2006$ & 2 & - \\
\cline { 2 - 4 } & $\mathrm{P} 100 / 2013$ & 1.933 & -3.35 \\
\hline 4 storeys & $\mathrm{P} 100 / 2006$ & 1.87 & - \\
\cline { 2 - 4 } & $\mathrm{P} 100 / 2013$ & 1.933 & 3.37 \\
\hline 5 storeys & $\mathrm{P} 100 / 2006$ & 1.699 & - \\
\cline { 2 - 4 } & $\mathrm{P} 100 / 2013$ & 1.933 & 13.77 \\
\hline 6 storeys & $\mathrm{P} 100 / 2006$ & 1.537 & - \\
\cline { 2 - 4 } & $\mathrm{P} 100 / 2013$ & 1.88 & 22.32 \\
\hline
\end{tabular}


The values reveal an increase of the coefficient only for high structures, with the period large enough to obtain the c coefficient smaller than the upper bound.

Structures type A, designed according to P100-1/2006, were loaded with a seismic force evaluated according to the new code. Inter-storey drifts for the ULS and SLS were calculated using the provisions of the new code and the values are listed in table 4.

Table 4

Drift values obtained for the ULS and SLS for structure A

\begin{tabular}{|c|c|c|c|c|c|c|c|c|c|}
\hline & & \multicolumn{2}{|c|}{$\mathrm{d}_{\mathrm{r}, \mathrm{x}}^{\mathrm{ULS}} / \mathrm{h}<0.025 \mathrm{~h}$} & \multicolumn{2}{|c|}{$\mathrm{d}_{\mathrm{r}, \mathrm{Y}}^{\mathrm{ULS}} / \mathrm{h}<0.025 \mathrm{~h}$} & \multicolumn{2}{|c|}{$\mathrm{d}_{\mathrm{r}, \mathrm{x}} \mathrm{SLS} / \mathrm{h}$} & \multicolumn{2}{|c|}{$\mathrm{d}_{\mathrm{r}, \mathrm{y}}^{\mathrm{SLS}} / \mathrm{h}$} \\
\hline & & Value & $\begin{array}{c}\text { Increase } \\
\%\end{array}$ & Value & $\begin{array}{c}\text { Increase } \\
\%\end{array}$ & Value & $\begin{array}{c}\text { Increase } \\
\%\end{array}$ & Value & $\begin{array}{c}\text { Increase } \\
\%\end{array}$ \\
\hline \multirow{2}{*}{$\begin{array}{c}3 \\
\text { storeys }\end{array}$} & $\mathrm{P} 100 / 2006$ & 0.0248 & - & 0.0244 & - & 0.0049 & - & 0.0049 & - \\
\hline & $\mathrm{P} 100 / 2013$ & 0.0272 & 10 & 0.0268 & 10 & 0.007 & 43 & 0.007 & 43 \\
\hline \multirow{2}{*}{$\begin{array}{c}4 \\
\text { storeys }\end{array}$} & $\mathrm{P} 100 / 2006$ & 0.0249 & - & 0.0236 & - & 0.0053 & - & 0.0051 & - \\
\hline & $\mathrm{P} 100 / 2013$ & 0.0292 & 17 & 0.0276 & 17 & 0.0076 & 43 & 0.0074 & 43 \\
\hline \multirow{2}{*}{$\begin{array}{c}5 \\
\text { storeys }\end{array}$} & $\mathrm{P} 100 / 2006$ & 0.025 & - & 0.0229 & - & 0.0059 & - & 0.0054 & - \\
\hline & $\mathrm{P} 100 / 2013$ & 0.0302 & 21 & 0.0277 & 21 & 0.0083 & 43 & 0.0079 & 43 \\
\hline \multirow{2}{*}{$\begin{array}{c}6 \\
\text { storeys }\end{array}$} & $\mathrm{P} 100 / 2006$ & 0.0249 & - & 0.0231 & - & 0.0065 & - & 0.0061 & - \\
\hline & P100/2013 & 0.0305 & 23 & 0.0283 & 23 & 0.0092 & 43 & 0.0086 & 43 \\
\hline
\end{tabular}

where:

$\mathrm{d}^{\mathrm{x}}{ }_{\mathrm{re}}, \mathrm{d}^{\mathrm{y}}{ }_{\mathrm{re}}$ - the drift values established with an elastic static computation, using the seismic design loads on the two main directions of the building

$\mathrm{d}_{\mathrm{r}, \mathrm{x}}$ ULS, $\mathrm{d}_{\mathrm{r}, \mathrm{y}}$ ULS - the design drift values obtained using the seismic loads for ULS, in the two main directions of the structure

$\mathrm{h}$ - the storey height

It is noticed that an increase of the displacement amplification coefficient c, correlated with an increase of the base shear force, leads to a rise of these displacements. The influence of the new code is more significant for higher structures.

The increase of $43 \%$ for the drifts computed for the serviceability limit state is because these buildings were classified as second class of importance. For an ordinary building, from the third class of importance, the increase would be equal to $13.6 \%$, considering that the same amplification factor $v=0.5$ was used according to both codes.

For structure B, designed according to both seismic codes, the following data, shown in table 5, for c coefficient were obtained:

Values of displacement amplification coefficient for structure B

\begin{tabular}{|c|c|c|c|}
\cline { 3 - 4 } \multicolumn{2}{c|}{} & \multicolumn{2}{c|}{$c$} \\
\cline { 3 - 4 } \multicolumn{2}{c|}{$\begin{array}{c}3 \\
\text { storeys }\end{array}$} & Value & Increase $\%$ \\
\cline { 2 - 4 } & $\mathrm{P} 100 / 2006$ & 2 & - \\
\hline $\begin{array}{c}4 \\
\text { storeys }\end{array}$ & $\mathrm{P} 100 / 2013$ & 1.933 & -3.35 \\
\cline { 2 - 4 } & $\mathrm{P} 100 / 2006$ & 1.93 & - \\
\hline $\begin{array}{c}5 \\
\text { storeys }\end{array}$ & $\mathrm{P} 100 / 2013$ & 1.933 & -0.15 \\
\cline { 2 - 4 } & $\mathrm{P} 100 / 2006$ & 1.817 & - \\
\hline $\begin{array}{c}6 \\
\text { storeys }\end{array}$ & $\mathrm{P} 100 / 2013$ & 1.933 & 6.38 \\
\cline { 2 - 4 } & $\mathrm{P} 100 / 2006$ & 1.624 & - \\
\hline
\end{tabular}


The type B structures, designed according to P100-1/2006, were loaded with a seismic force evaluated according to the new code. Inter-storey drifts for the ULS and SLS were calculated using the provisions of the new code and the values are listed in table 6.

Table 6

Drift values obtained for the ULS and SLS for structure B

\begin{tabular}{|c|c|c|c|c|c|c|c|c|c|}
\hline & & \multicolumn{2}{|c|}{$\mathrm{d}_{\mathrm{r}, \mathrm{x}} \mathrm{ULS} / \mathrm{h}<0.025 \mathrm{~h}$} & \multicolumn{2}{|c|}{$\mathrm{d}_{\mathrm{r}, \mathrm{y}}^{\mathrm{ULS}} / \mathrm{h}<0.025 \mathrm{~h}$} & \multicolumn{2}{|c|}{$\mathrm{d}_{\mathrm{r}, \mathrm{x}} \mathrm{SLS} / \mathrm{h}$} & \multicolumn{2}{|c|}{$\mathrm{d}_{\mathrm{r}, \mathrm{y}}^{\mathrm{SLS}} / \mathrm{h}$} \\
\hline & & Value & $\begin{array}{c}\text { Increase } \\
\% \\
\end{array}$ & Value & $\begin{array}{c}\text { Increase } \\
\% \\
\end{array}$ & Value & $\begin{array}{c}\text { Increase } \\
\% \\
\end{array}$ & Value & $\begin{array}{c}\text { Increase } \\
\% \\
\end{array}$ \\
\hline \multirow{2}{*}{$\begin{array}{c}3 \\
\text { storeys }\end{array}$} & $\mathrm{P} 100 / 2006$ & 0.0176 & - & 0.0205 & - & 0.0035 & - & 0.0041 & - \\
\hline & $\mathrm{P} 100 / 2013$ & 0.0193 & 10 & 0.0225 & 10 & 0.0050 & 43 & 0.0059 & 43 \\
\hline \multirow{2}{*}{$\begin{array}{c}4 \\
\text { storeys }\end{array}$} & $\mathrm{P} 100 / 2006$ & 0.0212 & - & 0.0247 & - & 0.0044 & - & 0.0051 & - \\
\hline & $\mathrm{P} 100 / 2013$ & 0.0242 & 14 & 0.0281 & 14 & 0.0063 & 43 & 0.0073 & 43 \\
\hline \multirow{2}{*}{$\begin{array}{c}5 \\
\text { storeys }\end{array}$} & $\mathrm{P} 100 / 2006$ & 0.0208 & - & 0.024 & - & 0.0046 & - & 0.0053 & - \\
\hline & $\mathrm{P} 100 / 2013$ & 0.0249 & 20 & 0.0286 & 20 & 0.0065 & 43 & 0.0075 & 43 \\
\hline \multirow{2}{*}{$\begin{array}{c}6 \\
\text { storeys }\end{array}$} & $\mathrm{P} 100 / 2006$ & 0.0213 & - & 0.0245 & - & 0.0052 & - & 0.006 & - \\
\hline & $\mathrm{P} 100 / 2013$ & 0.0258 & 21 & 0.0297 & 21 & 0.0074 & 43 & 0.0086 & 43 \\
\hline
\end{tabular}

After dimensioning the cross-sections of the concrete elements for both types of structures $\mathrm{A}$ and $\mathrm{B}$, in order to fulfill the stiffness conditions, it was discovered that the total volume of concrete increased, due to regulations of Code P100-1/2013, with values listed in table 7 .

Table 7

The concrete consumption $\left(\mathrm{m}^{3}\right)$

\begin{tabular}{|c|c|c|c|c|c|}
\hline & & \multicolumn{2}{|c|}{ STRUCTURE A } & \multicolumn{2}{|c|}{ STRUCTURE B } \\
\hline & & $\begin{array}{c}\text { Concrete } \\
\text { volum }\left(\mathrm{m}^{3}\right)\end{array}$ & $\begin{array}{c}\text { Increase } \\
\% \\
\end{array}$ & $\begin{array}{c}\text { Concrete } \\
\text { volum }\left(\mathrm{m}^{3}\right)\end{array}$ & $\begin{array}{c}\text { Increase } \\
\% \\
\end{array}$ \\
\hline \multirow{2}{*}{$\begin{array}{c}3 \\
\text { storeys }\end{array}$} & $\mathrm{P} 100 / 2006$ & 1290 & - & 1335 & - \\
\hline & $\mathrm{P} 100 / 2013$ & 1320 & 2 & 1335 & 0 \\
\hline \multirow{2}{*}{$\begin{array}{c}4 \\
\text { storeys }\end{array}$} & P100/2006 & 1850 & - & 1835 & - \\
\hline & $\mathrm{P} 100 / 2013$ & 1955 & 6 & 1900 & 4 \\
\hline \multirow{2}{*}{$\begin{array}{c}5 \\
\text { storeys }\end{array}$} & P100/2006 & 2510 & - & 2455 & - \\
\hline & $\mathrm{P} 100 / 2013$ & 2860 & 14 & 2650 & 8 \\
\hline \multirow{2}{*}{$\begin{array}{c}6 \\
\text { storeys }\end{array}$} & P100/2006 & 3520 & - & 3060 & - \\
\hline & P100/2013 & 4615 & 31 & 4090 & 34 \\
\hline
\end{tabular}

The minimum clear height recommended for office buidings by the scientific literature is around $2.70 \mathrm{~m}$ [12]. The designed structures have the storey height of $3.50 \mathrm{~m}$ and the depth of the transversal beams of $75 \mathrm{~cm}$. Therefore it was chosen to increase only the sections of the columns in order to satisfy drift limitations prescribed by the codes. For this reason, as there is no increase in the beam stiffness, the increase of the seismic force according to code P100-1/2013 did not lead to a significant increase of efforts in the beams and therefore the longitudinal reinforcement remained the same.

Obviously, increasing the seismic force caused a corresponding augmentation of the columns forces.

After sizing the longitudinal reinforcement in columns, both for the edge and central columns, the areas were given by the minimum reinforcement percentage of $1 \%$. As the areas of the column sections are increasing, the areas of the longitudinal reinforcements are increasing with the same percentage. It can be noticed that a very large increase of concrete sections of the columns has negative implications on concrete consumption, but also on the increase the amount of reinforcement, as seen in table 8 . 
Longitudinal reinforcement for columns

\begin{tabular}{|c|c|c|c|c|}
\hline & & & \\
\hline & & & $\begin{array}{c}\text { COLUMNS } \\
\text { CONCRETE } \\
\text { SECTIONS }(\mathrm{cm})\end{array}$ & $\begin{array}{c}\text { COLUMNS } \\
\text { REINFORCEMENT } \\
\text { Increase } \%\end{array}$ \\
\hline \multirow{8}{*}{ Structure A } & \multirow{2}{*}{$\begin{array}{c}3 \\
\text { storeys }\end{array}$} & $\mathrm{P} 100 / 2006$ & $55 \times 55$ & - \\
\hline & & $\mathrm{P} 100 / 2013$ & $65 \times 65$ & $40 \%$ \\
\hline & \multirow{2}{*}{$\begin{array}{c}4 \\
\text { storeys }\end{array}$} & $\mathrm{P} 100 / 2006$ & $70 \times 70$ & - \\
\hline & & P100/2013 & $80 \times 80$ & $30 \%$ \\
\hline & \multirow{2}{*}{$\begin{array}{c}5 \\
\text { storeys }\end{array}$} & P100/2006 & $85 \times 85$ & - \\
\hline & & P100/2013 & $105 \times 105$ & $52 \%$ \\
\hline & \multirow{2}{*}{$\begin{array}{c}6 \\
\text { storeys }\end{array}$} & P100/2006 & $105 \times 105$ & - \\
\hline & & P100/2013 & $150 \times 150$ & $104 \%$ \\
\hline \multirow{8}{*}{ Structure B } & \multirow{2}{*}{$\begin{array}{c}3 \\
\text { storeys }\end{array}$} & $\mathrm{P} 100 / 2006$ & $50 \times 50$ & - \\
\hline & & P100/2013 & $50 \times 50$ & 0\% \\
\hline & \multirow{2}{*}{$\begin{array}{c}4 \\
\text { storeys }\end{array}$} & P100/2006 & $55 \times 55$ & - \\
\hline & & P100/2013 & $60 \times 60$ & $19 \%$ \\
\hline & \multirow{2}{*}{$\begin{array}{c}5 \\
\text { storeys }\end{array}$} & P100/2006 & $65 \times 65$ & - \\
\hline & & $\mathrm{P} 100 / 2013$ & $75 \times 75$ & $33 \%$ \\
\hline & \multirow{2}{*}{$\begin{array}{c}6 \\
\text { storeys }\end{array}$} & $\mathrm{P} 100 / 2006$ & $70 \times 70$ & - \\
\hline & & P100/2013 & $105 \times 105$ & $225 \%$ \\
\hline
\end{tabular}

\section{Comments and conclusions}

The author analyzed the influence of changes in the design codes on two types of reinforced concrete frame structures. The type A and B structures are used for office buildings, having bays and story height appropriate to this purpose. After comparing the results the following conclusions were drawn

- There is an increase of the base shear force of $13.6 \%$ which led to an increase of the drifts computed for ULS with different values, depending on the displacement amplification coefficient.

- Resizing the elements of the structures in order to fulfill the stiffness conditions required by the seismic force augmentation led to an increase of concrete volume between 2 and $33 \%$ for type A frame structure and between 0 and $34 \%$ for the type B frame structure, depending on the number of storeys, with greater increases for higher structures.

- For type A structures, for 5 and 6 storeys, the cross-sections of the columns are significantly increased therefore a high building with spans $\mathrm{x}$ bays of $9 \times 6 \mathrm{~m}$ and level height of $3.50 \mathrm{~m}$ can no longer use just a RC frame structural system.

- For type A structures it is observed that the concrete sections of the columns increased from $40 \%$ for the 3 storey building up to $104 \%$ for the 6 storey building. The area of the longitudinal reinforcement in columns was obtained mainly due to the minimum percentage conditions and not necessarily to the size of the forces, which implies an increase of the rebars up to $104 \%$ for the 6 storey structure. 
- For type B structures, the concrete sections of the columns also increased from $0 \%$ for the 3 storey building to $225 \%$ for the 6 storey building. The longitudinal reinforcement of the columns increased with the same values, due to the minimum percentage.

- For 6 levels, structure B has the cross-sections of the columns highly increased, indicating that starting with this height another type of structure should be used.

- It can be observed that the type B structures, the tube type, behaves better than the type A structures to the seismic action and can take higher values of seismic forces with smaller increases of element dimensions and implicitly, with lower costs.

\section{References}

[1].Ministry of Transport, Constructions and Tourism (2006) Seismic Design Code. Part 1 - Design Provisions for Buildings. P100-1/2006. Bucharest, Romania.

[1] Ministry of Regional Development and Public Administration (2013). Seismic Design Code. Part 1 - Design Provisions for Buildings. P100-1/2013. Bucharest, Romania

[2] Ministry of Regional Development and Public Administration (2012). Design code: basis of structural design. CR0/2012. Bucharest, Romania.

[3] Romanian Association for Standardization (2006). Eurocode 2: Design of concrete structures - Part 1-1: General rules and rules for buildings. SR EN1992-1-1. Bucharest, Romania.

[4] Dabija F. E. (2010) "Building Design“"(Vol. 3), Ed. Conspress

[5] Kiss Z., Onet T. (2008) “Proiectarea structurilor de beton după SR EN 1992-1”, Ed. Abel

[6] Paulay T., Bachman H., Moser K. (1997) "Earthquake design of reinforced concrete buildings/Proiectarea structurilor de beton armat la acţiuni seismice" (Trad. Crainic L.), Ed. Tehnică, Bucureşti

[7] Tang S., Chin I. (1990) "Structural Engineering Handbook" $3^{\text {rd }}$ Edition (Gaylord E.H.Jr.,Gaylord C.N. - Editors), Section 21, Buildings, General Design Considerations, Ed. McGraw-Hill Publishing Company

[8] Sev A., Ozgen A. (2009) "Space Efficiency in High-Rise Office Buildings", METU JFA 2009/2, p. 69-89

[9] Postelnicu T., Popa V. (2009). "Proiectarea nodurilor cadrelor de beton armat in codurile de proiectare actuale". AICPS Journal no. 2-3/2009. Bucharest: Marlink.

[10] Ghita, A.M. (2013) "Contribuţii la proiectarea unor soluţii structurale şi funcţionale eficiente pentru clădiri de birouri etajate/Contributions To The Design Of Efficient Structural And Functional Solutions For Multi-Storey Office Buildings", PhD Thesis, Technical University Of Civil Engineering Bucharest, Romania

[11] Neufert E., Neufert P. (2012) “Architects’ Data”, Wiley-Blackwell 